\title{
THE LIVER LIPIDS AND THEIR DISTRIBUTION IN DISEASE. AN ANALYSIS OF 60 HUMAN LIVERS ${ }^{1}$
}

\author{
By ELAINE P. RALLI, KARL PALEY, ANd SAUL H. RUBIN \\ (From the Department of Medicine, New York University, and the Third (New York \\ University) Medical Division of Bellevue Hospital, New York City)
}

(Received for publication April 4, 1941)

The lipid distribution in normal human livers and in cases of cirrhosis and fatty infiltration of the liver was reported in a previous study (1). As a corollary to these observations, the livers of patients dying from other diseases were analyzed for their lipid content and distribution. The question as to whether diseases other than those directly affecting the liver may alter the lipid content and its distribution in the liver is of interest because the functions of the liver are so varied that it tends to be involved in almost any profound disturbance in the body.

The clinical methods available for determining the function of the liver in relation to fat are limited. At present, the most satisfactory index of a lipid disturbance is the ratio of free to total cholesterol in the plasma. This is altered in cirrhosis, fatty infiltration of the liver, and in parenchymatous liver disease (2), but this ratio does not give information as to the total lipid content of the liver, or the other lipid fractions.

The determinations that we are reporting were made to ascertain the changes that might occur in the liver lipids in diseases other than those directly affecting the liver. These values are compared to the normal liver lipid values obtained by analysis from a group of 25 normal subjects reported in the previous study (1). The average total liver lipid for this group of normals was 4.98 grams per 100 grams of wet liver. The range was from 2.42 to 8.41 grams per cent. The average fatty acids were 3.50 grams per cent, the average phospholipids 2.08 grams per cent, and the average neutral fat 2.26 grams per cent; the average total cholesterol was $283 \mathrm{mgm}$. per cent and the average free cholesterol 204 mgm. per cent.

Liver samples were obtained in almost all of the cases within 24 hours after death. As re-

1 This research was aided by a grant from the Milbank Memorial Foundation. ported previously (1), the fraction which is most subject to change as a result of standing is the phospholipid fraction, which tends to decrease after about 5 hours. There seems to be no further decrease after 24 hours. Lipids and their fractions were done by the methods previously described from this laboratory (3).

Samples of liver were obtained from patients dying of the following diseases: (1) Acute infections, such as meningitis, pneumonia, peritonitis, and septicemia; (2) chronic infections, including tuberculosis, subacute bacterial endocarditis, syphilis and osteomyelitis; (3) malignancy; (4) metabolic diseases; and (5) cardiovascular diseases. The diseases of 4 of the patients in the metabolic group were complicated by an acute infection (Numbers $3,7,54,88$ ), and 2 (Numbers 10 and 92 ) cases in this group also had some form of heart disease. The liver values for these 6 cases are entered in both pathological groups. The acute infections were subdivided into two groups, as 5 of these patients were diagnosed pathologically as having fatty infiltration or cirrhosis of the liver.

\section{RESULTS}

In Table $I$ are the findings in 21 cases in whom death was due to some acute infection. Of these 21 cases, 16 had no evidence of cirrhosis or fatty infiltration of the liver. The average weight of the livers in this group was 1760 grams. The lowest weight was 1400 grams and the greatest was 2900 grams. The average total liver lipid was 4.72 grams per cent. In one liver the total lipid was 9 grams per cent, but in the majority of the group the total lipid was $\mathbf{5}$ grams per cent or less. The lowest lipid value in the group was 2.3 grams per cent. The average phospholipid was 1.89 grams per cent and the average of the neutral fat was 2.41 grams per cent. The total cholesterol averaged $269 \mathrm{mgm}$. per cent. These 
TABLE I

Acute infections with and without cirrhosis or fatty infiltration of the liver

\begin{tabular}{|c|c|c|c|c|c|c|c|c|c|c|c|c|}
\hline \multirow{2}{*}{$\begin{array}{l}\text { Number } \\
\text { case }\end{array}$} & \multirow{2}{*}{ Age } & \multirow{2}{*}{ Sex } & \multirow{2}{*}{$\begin{array}{l}\text { Nutri- } \\
\text { tion of } \\
\text { patient }\end{array}$} & \multirow{2}{*}{$\begin{array}{c}\text { Weight } \\
\text { of } \\
\text { liver }\end{array}$} & \multirow{2}{*}{$\begin{array}{l}\text { Total } \\
\text { lipid }\end{array}$} & \multirow{2}{*}{$\begin{array}{c}\text { Unsa- } \\
\text { poni- } \\
\text { fied }\end{array}$} & \multirow{2}{*}{$\begin{array}{c}\text { Fatty } \\
\text { acid }\end{array}$} & \multicolumn{2}{|c|}{ Cholesterol } & \multirow{2}{*}{$\begin{array}{l}\text { Phos- } \\
\text { pho- } \\
\text { lipids }\end{array}$} & \multirow{2}{*}{$\begin{array}{l}\text { Neu- } \\
\text { tral } \\
\text { fat }\end{array}$} & \multirow{2}{*}{ Pathological findings and diagnoses } \\
\hline & & & & & & & & Free & Total & & & \\
\hline & & & & grams & $\begin{array}{c}\text { grams } \\
\text { per } \\
\text { cent }\end{array}$ & $\begin{array}{c}\text { grams } \\
\text { per } \\
\text { cent }\end{array}$ & $\begin{array}{c}\text { grams } \\
\text { per } \\
\text { cent }\end{array}$ & & recut & $\begin{array}{c}\text { grams } \\
\text { per } \\
\text { cent }\end{array}$ & $\begin{array}{c}\text { grams } \\
\text { per } \\
\text { cent }\end{array}$ & \\
\hline
\end{tabular}

ACUTE INFECTIONS WITHOUT CIRRHOSIS OF THE LIVER

\begin{tabular}{|c|c|c|c|c|c|c|c|c|c|c|c|c|}
\hline $\begin{array}{l}3 \\
9\end{array}$ & $\begin{array}{l}50 \\
65\end{array}$ & $\begin{array}{l}\mathbf{M} \\
\mathbf{M}\end{array}$ & $\begin{array}{l}\text { Fair } \\
\text { Poor }\end{array}$ & $\begin{array}{l}1770 \\
1650\end{array}$ & $\begin{array}{l}4.96 \\
2.44\end{array}$ & $\begin{array}{l}0.62 \\
0.80\end{array}$ & $\begin{array}{l}4.46 \\
1.92\end{array}$ & $\begin{array}{l}189 \\
231\end{array}$ & $\begin{array}{l}259 \\
232\end{array}$ & $\begin{array}{l}1.65 \\
1.11\end{array}$ & $\begin{array}{l}3.48 \\
1.24\end{array}$ & $\begin{array}{l}\text { Meningococcus meningitis, diabetes mellitus } \\
\text { Streptococcus hemolyticus endocarditis, }\end{array}$ \\
\hline $\begin{array}{l}19 \\
59\end{array}$ & $\begin{array}{l}18 \\
32\end{array}$ & $\begin{array}{l}\mathbf{F} \\
\mathbf{M}\end{array}$ & $\begin{array}{l}\text { Good } \\
\text { Fair }\end{array}$ & $\begin{array}{l}1780 \\
1860\end{array}$ & $\begin{array}{l}7.00 \\
4.51\end{array}$ & $\begin{array}{l}0.14 \\
0.66\end{array}$ & $\begin{array}{l}5.51 \\
3.16\end{array}$ & & $\begin{array}{l}415 \\
208\end{array}$ & $\begin{array}{l}3.61 \\
1.75\end{array}$ & $\begin{array}{l}2.98 \\
2.13\end{array}$ & mal liver \\
\hline 42 & & $\mathbf{M}$ & Good & 1750 & 5. & 0.60 & 4.40 & & 298 & 1.86 & 3.29 & $\mathrm{~L}$ \\
\hline 51 & 35 & $\mathbf{M}$ & & 1800 & 5. & & 4.87 & & 210 & & 4.10 & 0 \\
\hline 86 & $\begin{array}{l}40 \\
45\end{array}$ & $\mathbf{M}$ & Good & 14 & 90 & 0.82 & 7.33 & & & & & liver, chronic chole- \\
\hline & & & & & & & & & & & & \\
\hline 29 & 45 & $\mathbf{M}$ & & 2050 & 3.15 & 0.72 & 2.17 & & 263 & 1.22 & 1.46 & Dscesses \\
\hline $\begin{array}{l}23 \\
88\end{array}$ & $\left|\begin{array}{l}50 \\
67\end{array}\right|$ & $\frac{\mathbf{M}}{\mathbf{F}}$ & Poor & $\begin{array}{l}2740 \\
1400\end{array}$ & $\begin{array}{l}3.63 \\
3.92\end{array}$ & & & & 287 & 2.80 & 0.92 & $\mathrm{BrC}$ \\
\hline 67 & \begin{tabular}{|l}
01 \\
50
\end{tabular} & $\begin{array}{l}\mathbf{r} \\
\mathbf{M}\end{array}$ & $\begin{array}{l}\text { Obese } \\
\text { Fair }\end{array}$ & $\begin{array}{l}14 \\
16\end{array}$ & 4. & 0.69 & 3. & & & 2.08 & 2. & of ileum \\
\hline 70 & 50 & $\mathbf{M}$ & Go & 13 & 4. & & 3. & & & & 2.93 & \\
\hline & & $\mathbf{M}$ & & 13 & 3 & 0. & 2.0 & & & & & c failure, \\
\hline 18 & 53 & $\mathbf{M}$ & Good & 1440 & 6.91 & 0.71 & 4.45 & & 287 & 2.06 & 3.20 & ent meningitis, fract \\
\hline $\begin{array}{c}105 \\
\text { Average }\end{array}$ & $\begin{array}{l}71 \\
50\end{array}$ & $\mathbf{M}$ & Poor & $\begin{array}{l}1300 \\
1760\end{array}$ & $\begin{array}{l}2.35 \\
4.72\end{array}$ & 0.65 & 3.67 & 21 & 269 & 1.89 & 2.41 & Acute cystitis, purulent \\
\hline
\end{tabular}

ACUTE INFECTIONS WITH CIRRHOSIS OR FATTY INFILTRATION OF THE LIVER

\begin{tabular}{|c|c|c|c|c|c|c|c|c|c|c|c|}
\hline 56 & 35 & $\mathbf{F}$ & Poor & 2450 & 11.50 & 0.84 & 10.20 . & 337 & 1.99 & 9.28 & Streptococcus meningitis, fatty and cirrhotic \\
\hline $\begin{array}{l}31 \\
75\end{array}$ & $\begin{array}{l}38 \\
41\end{array}$ & $\begin{array}{l}\mathbf{M} \\
\mathbf{M}\end{array}$ & $\begin{array}{l}\text { Good } \\
\text { Poor }\end{array}$ & $\begin{array}{l}1650 \\
1910\end{array}$ & $\begin{array}{r}7.68 \\
16.10\end{array}$ & $\begin{array}{l}0.74 \\
0.39\end{array}$ & $\begin{array}{r}6.72 \\
14.90\end{array}$ & 338 & 1.80 & 5.71 & $\begin{array}{l}\text { Lobar pneumonia, cirrhosis of the liver } \\
\text { Chronic alcoholism, lobar pneumonia, fatty }\end{array}$ \\
\hline 58 & 50 & $\mathbf{M}$ & Poor & 1950 & 28.10 & 1.00 & 25.50 & 389 & 1.97 & 25.30 & Alcoholism, lobular pneumonia, fatty and \\
\hline 30 & 65 & $\mathbf{F}$ & Poor & 1170 & 14.05 & 0.97 & 13.60 & 238 & 2.53 & 12.50 & $\begin{array}{l}\text { Lobular pneumonia, fatty liver, Paget's } \\
\text { disease }\end{array}$ \\
\hline Average & 43 & & & 1835 & 15.48 & 0.79 & 14.18 & 326 & 2.07 & 13.20 & \\
\hline
\end{tabular}

figures are almost identical to the average of the values obtained in the 25 normal subjects. In the 5 cases in whom there was cirrhosis or fatty infiltration of the liver there was a definite increase in the total lipid and fatty acids. The average total liver lipid for the group was 15.48 grams per cent. The phospholipids were a trifle higher than in the other patients dying of acute infections, and the neutral fat was, of course, increased, since any increase in total lipid is due outstandingly to the increase in the neutral fat fraction. The average of the total cholesterol was increased.

These figures correspond with the liver lipid values obtained in the 25 alcoholic patients re- ported previously, with the exception that the phospholipid fraction is somewhat higher in this group of 5 cases. Free cholesterol determinations were not done in these 5 cases but any increase in the total cholesterol is probably due to an increase in the esterified fraction.

A report of the determinations on 10 cases dying of chronic infection is made in Table II. Of these, 3 had tuberculosis, 1 had a lung abscess, 2 had endocarditis, 1 had a bronchiectasis, 1 died of malaria, another of luetic heart disease, and 1 of chronic cholecystitis. In 3 of the patients the total lipid in the liver was increased. One of these was the case with lung abscess, and the other 
TABLE II

Chronic infections

\begin{tabular}{|c|c|c|c|c|c|c|c|c|c|c|c|c|}
\hline \multirow{2}{*}{$\begin{array}{c}\text { Number } \\
\text { case }\end{array}$} & \multirow[b]{2}{*}{ Age } & \multirow[b]{2}{*}{ Sex } & \multirow{2}{*}{$\begin{array}{c}\text { Nu- } \\
\text { tri- } \\
\text { tion } \\
\text { of } \\
\text { pa- } \\
\text { tient }\end{array}$} & \multirow{2}{*}{$\begin{array}{c}\text { Weight } \\
\text { of } \\
\text { liver }\end{array}$} & \multirow{2}{*}{$\begin{array}{l}\text { Total } \\
\text { lipid }\end{array}$} & \multirow{2}{*}{$\begin{array}{l}\text { Unsa- } \\
\text { poni- } \\
\text { fied }\end{array}$} & \multirow{2}{*}{$\begin{array}{c}\text { Fatty } \\
\text { acid }\end{array}$} & \multicolumn{2}{|c|}{ Cholesterol } & \multirow{2}{*}{$\begin{array}{l}\text { Leci- } \\
\text { thin }\end{array}$} & \multirow{2}{*}{$\begin{array}{c}\text { Neu- } \\
\text { tral } \\
\text { fat }\end{array}$} & \multirow[b]{2}{*}{ Pathology of the liver and other disease processes } \\
\hline & & & & & & & & Free & Total & & & \\
\hline & & & & grams & $\begin{array}{c}\text { grams } \\
\text { per } \\
\text { cent }\end{array}$ & $\begin{array}{c}\text { grams } \\
\text { per } \\
\text { cent }\end{array}$ & $\begin{array}{c}\text { grams } \\
\text { per } \\
\text { cent }\end{array}$ & & cent & $\begin{array}{c}\text { grams } \\
\text { per } \\
\text { cent }\end{array}$ & $\begin{array}{c}\text { grams } \\
\text { per } \\
\text { cent }\end{array}$ & \\
\hline $\begin{array}{r}7 \\
11 \\
36 \\
73 \\
78 \\
97 \\
82 \\
84 \\
95 \\
21\end{array}$ & $\begin{array}{l}57 \\
62 \\
43 \\
41 \\
30 \\
27 \\
45 \\
38 \\
49 \\
23\end{array}$ & $\begin{array}{l}\mathbf{M} \\
\mathbf{M} \\
\mathbf{M} \\
\mathbf{M} \\
\mathbf{M} \\
\mathbf{M} \\
\mathbf{M} \\
\mathbf{M} \\
\mathbf{M} \\
\mathbf{F}\end{array}$ & $\begin{array}{l}\text { Obese } \\
\text { Poor } \\
\text { Poor } \\
\text { Good } \\
\text { Good } \\
\text { Good } \\
\text { Good } \\
\text { Good } \\
\text { Poor } \\
\text { Good }\end{array}$ & \begin{tabular}{|l|}
1440 \\
1370 \\
2000 \\
1620 \\
2090 \\
1550 \\
1720 \\
1850 \\
2330 \\
1430
\end{tabular} & $\begin{array}{r}4.03 \\
12.05 \\
3.24 \\
2.22 \\
3.43 \\
4.44 \\
15.27 \\
13.30 \\
3.43 \\
3.59\end{array}$ & $\begin{array}{l}1.06 \\
1.32 \\
1.20 \\
0.55 \\
0.58 \\
0.74 \\
0.58 \\
0.59 \\
0.65 \\
0.61\end{array}$ & \begin{tabular}{|r|}
2.33 \\
10.80 \\
2.29 \\
1.41 \\
2.50 \\
2.96 \\
14.13 \\
11.91 \\
2.09 \\
2.06
\end{tabular} & $\begin{array}{l}294 \\
221\end{array}$ & $\begin{array}{l}323 \\
312 \\
242\end{array}$ & $\begin{array}{l}1.43 \\
0.87 \\
1.77 \\
1.16\end{array}$ & $\begin{array}{r}1.43 \\
10.70 \\
1.16 \\
0.64\end{array}$ & $\begin{array}{l}\text { Bronchiectasis, cerebral arteriosclerosis } \\
\text { Lung abscess } \\
\text { Subacute bacterial endocarditis, aortic valvulitis } \\
\text { Malaria, liver normal } \\
\text { Chronic cholecystitis, emphysema, liver normal } \\
\text { Luetic aortitis, liver normal } \\
\text { Chronic alcoholic, pulmonary tuberculosis; fatty liver } \\
\text { Chronic alcoholic, pulmonary tuberculosis } \\
\text { Osteomyelitis, endocarditis, slightly fatty liver } \\
\text { Tuberculous meningitis and peritonitis, fatty liver with peri- }\end{array}$ \\
\hline Average & 41 & & & 1760 & 6.90 & 0.76 & 5.63 & 258 & 279 & 1.98 & 2.33 & \\
\hline
\end{tabular}

2 were chronic alcoholics who had pulmonary tuberculosis. In the remaining cases, the total lipid was lower than the average for the normal livers, being about 3 grams per cent in most of the cases. The 2 patients who were chronic alcoholics also had pulmonary tuberculosis. As it was noted in the previous study that an increase in liver lipid was found in the livers of patients with a history of chronic alcoholism, it is probable that tuberculosis was not the cause of this increased lipid.

There were 7 patients dying with some form of malignancy (Table III). One of the cases, a patient with lymphosarcoma and metastatic nodules in the liver, had a total liver lipid of $\mathbf{1 5}$ grams per cent. It is interesting that most of these patients, several of whom had metastatic involvement of the liver, showed no change in the lipid content of the liver or its distribution. In 2 of the cases the total lipid values were somewhat lower than the usual normal values.
Table IV gives the observations on 12 patients with some metabolic disturbance. Three of these patients had diabetes, 8 were obese and had some other disease process, and 1 was a patient with Paget's disease of the bone. Interestingly enough, none of the diabetic patients had an increase in the total liver lipid. In 3 patients in this group the total liver lipids were elevated. Of these, 1 was the patient with Paget's disease, 1 was a patient with obesity, and 1 was a patient with coronary thrombosis and obesity. Four of the obese patients were killed in accidents, and no other pathological changes were found.

Table $\mathrm{V}$ presents the findings on 16 patients dying from some form of cardiovascular disease. Four of these had elevated total liver lipids; of these 4, 2 had coronary sclerosis (1 of whom in addition was an alcoholic), 1 had a coronary thrombosis, and 1 died of hypertensive heart disease. The last subject was also obese. The aver-

TABLE III

Malignant diseases

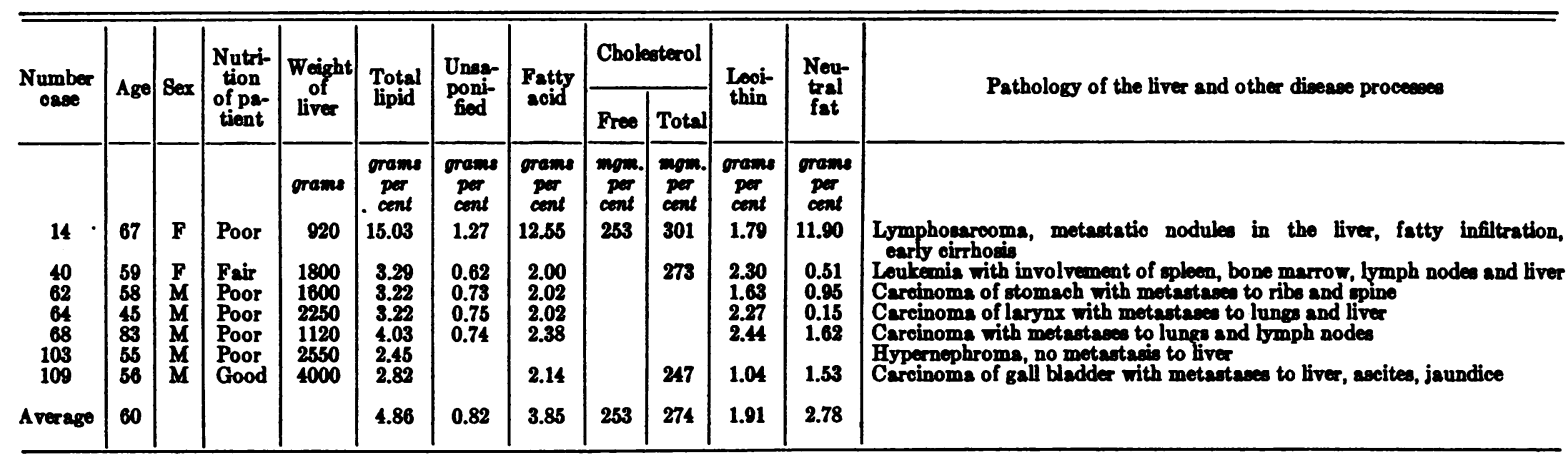


TABLE IV

Disease of metabolism

\begin{tabular}{|c|c|c|c|c|c|c|c|c|c|c|c|c|}
\hline \multirow{2}{*}{$\begin{array}{c}\text { Number } \\
\text { case }\end{array}$} & \multirow{2}{*}{ Age } & \multirow{2}{*}{ Sex } & \multirow{2}{*}{$\begin{array}{l}\text { Nutri- } \\
\text { tion } \\
\text { of pa- } \\
\text { tient }\end{array}$} & \multirow{2}{*}{$\begin{array}{l}\text { Weight } \\
\text { of } \\
\text { liver }\end{array}$} & \multirow{2}{*}{$\begin{array}{l}\text { Total } \\
\text { lipid }\end{array}$} & \multirow{2}{*}{$\begin{array}{l}\text { Unsa- } \\
\text { poni- } \\
\text { fied }\end{array}$} & \multirow{2}{*}{$\begin{array}{l}\text { Fatty } \\
\text { acid }\end{array}$} & \multicolumn{2}{|c|}{ Cholesterol } & \multirow{2}{*}{$\begin{array}{l}\text { Leci- } \\
\text { thin }\end{array}$} & \multirow{2}{*}{$\begin{array}{l}\text { Neu- } \\
\text { tral } \\
\text { fat }\end{array}$} & \multirow{2}{*}{ Pathology of the liver and other disease processes } \\
\hline & & & & & & & & Free & Total & & & \\
\hline & & & & grams & $\begin{array}{l}\text { grams } \\
\text { per } \\
\text { cent }\end{array}$ & $\begin{array}{l}\text { grams } \\
\text { per } \\
\text { cent }\end{array}$ & $\begin{array}{c}\text { grams } \\
\text { per } \\
\text { cent }\end{array}$ & $\begin{array}{l}\text { mom. } \\
\text { per } \\
\text { cent }\end{array}$ & $\begin{array}{c}\text { mom. } \\
\text { per } \\
\text { cent }\end{array}$ & $\begin{array}{c}\text { grams } \\
\text { per } \\
\text { cent }\end{array}$ & $\begin{array}{c}\text { grams } \\
\text { per } \\
\text { cent }\end{array}$ & - \\
\hline $\begin{array}{l}\mathbf{2} \\
\mathbf{3} \\
\mathbf{7}\end{array}$ & $\begin{array}{l}56 \\
50 \\
57\end{array}$ & $\begin{array}{l}\mathbf{F} \\
\mathbf{M} \\
\mathbf{M}\end{array}$ & $\begin{array}{l}\text { Poor } \\
\text { Fair } \\
\text { Obese }\end{array}$ & $\begin{array}{l}1475 \\
1770 \\
1440\end{array}$ & $\begin{array}{l}3.59 \\
4.96 \\
4.03\end{array}$ & $\begin{array}{l}0.77 \\
0.62 \\
1.06\end{array}$ & $\begin{array}{l}2.16 \\
4.46 \\
2.33\end{array}$ & $\begin{array}{l}253 \\
189 \\
294\end{array}$ & $\begin{array}{l}253 \\
259 \\
323\end{array}$ & $\begin{array}{l}1.86 \\
1.65 \\
1.43\end{array}$ & $\begin{array}{l}0.97 \\
3.48 \\
1.43\end{array}$ & $\begin{array}{l}\text { Diabetes mellitus, diabetio ketosis, normal liver, oholelithiasis } \\
\text { Diabetes mellitus, meningococcus meningitis, pericentral atrophy of the liver } \\
\text { Diabetes mellitus, mild obesity, lobular pneumonis, hypertensive and } \\
\text { arterial heart disease }\end{array}$ \\
\hline $\begin{array}{l}10 \\
22 \\
30 \\
32 \\
48 \\
52 \\
54 \\
88 \\
92\end{array}$ & $\begin{array}{l}\mathbf{5 0} \\
\mathbf{5 0} \\
\mathbf{6 5} \\
\mathbf{5 4} \\
\mathbf{5 0} \\
\mathbf{3 1} \\
\mathbf{4 5} \\
\mathbf{6 7} \\
\mathbf{5 0}\end{array}$ & $\begin{array}{l}\mathbf{F} \\
\mathbf{M} \\
\mathbf{F} \\
\mathbf{M} \\
\mathbf{F} \\
\mathbf{M} \\
\mathbf{F} \\
\mathbf{F} \\
\mathbf{M}\end{array}$ & $\begin{array}{l}\text { Obese } \\
\text { Obese } \\
\text { Poor } \\
\text { Obese } \\
\text { Obese } \\
\text { Obese } \\
\text { Obese } \\
\text { Obese } \\
\text { Obese }\end{array}$ & $\begin{array}{l}1330 \\
1875 \\
1170 \\
1730 \\
1640 \\
1660 \\
2900 \\
1400 \\
2490\end{array}$ & $\begin{array}{r}7.43 \\
6.06 \\
14.05 \\
6.61 \\
10.60 \\
7.72 \\
3.39 \\
3.92 \\
19.63\end{array}$ & $\begin{array}{l}0.83 \\
1.33 \\
0.97 \\
0.95 \\
0.96 \\
0.77 \\
0.54 \\
0.78 \\
0.46\end{array}$ & \begin{tabular}{|r}
6.17 \\
4.57 \\
13.60 \\
4.91 \\
8.90 \\
4.22 \\
2.26 \\
2.69 \\
18.71
\end{tabular} & $\begin{array}{l}259 \\
293\end{array}$ & $\begin{array}{l}335 \\
238 \\
201 \\
326 \\
333 \\
232 \\
\\
237\end{array}$ & $\begin{array}{l}1.31 \\
2.99 \\
2.53 \\
1.40 \\
2.01 \\
2.89 \\
1.87\end{array}$ & $\begin{array}{r}5.52 \\
2.68 \\
12.50 \\
4.21 \\
6.85 \\
2.35 \\
1.07\end{array}$ & $\begin{array}{l}\text { Arteriosclerotic heart disease, obesity, CPC of liver } \\
\text { Obesity, normal liver } \\
\text { Paget's disease, lobular pneumonia, fatty liver } \\
\text { Obesity, slightly fatty liver } \\
\text { Obesity, normal liver } \\
\text { Obesity, normal liver } \\
\text { Liver abscess, chronio cholecystitis, obesity } \\
\text { Bronohopneumonia, obesity, normal liver } \\
\text { Coronary thrombosis, fatty liver, obesity }\end{array}$ \\
\hline Average & 52 & & & 1740 & 7.67 & 0.84 & 6.25 & 258 & 274 & 1.99 & 4.11 & \\
\hline
\end{tabular}

age total cholesterol for the group was above the normal average. Otherwise, the findings did not show any very striking changes.

\section{DISCUSSION}

In 14 of the 60 cases the total liver lipids were increased. Of these 14 cases, 5 were patients dying from acute infections; of these 5,4 were found to have some cirrhosis of the liver and 2 had previous histories of alcoholism. Three of the 14 patients died of some chronic infection, and 2 of these were alcoholics. Of the remaining 6 patients in whom the liver lipids were increased, 1 was a patient with lymphosarcoma, 1 was an obese patient with no other complication, and 4 were patients with heart disease.
In the group of patients dying of chronic infections, and in the group of patients dying of some form of malignancy, the total liver lipids were slightly lower in several instances than the average normal value.

On the basis of the analyses done, the amount and character of the fat in the liver do not seem to be influenced significantly unless the liver itself is subject to disease. Cirrhosis of the liver, or the type of fatty infiltration that is seen most often in alcoholics, has more influence on the amount and distribution of the liver lipids than do other diseases. It is interesting that, in the very few diabetic cases analyzed, there was no appreciable increase in the amount of fat in the liver.

Breusch and Scalabrino (4) analyzed the livers

TABLE V

Cardiovascular disease

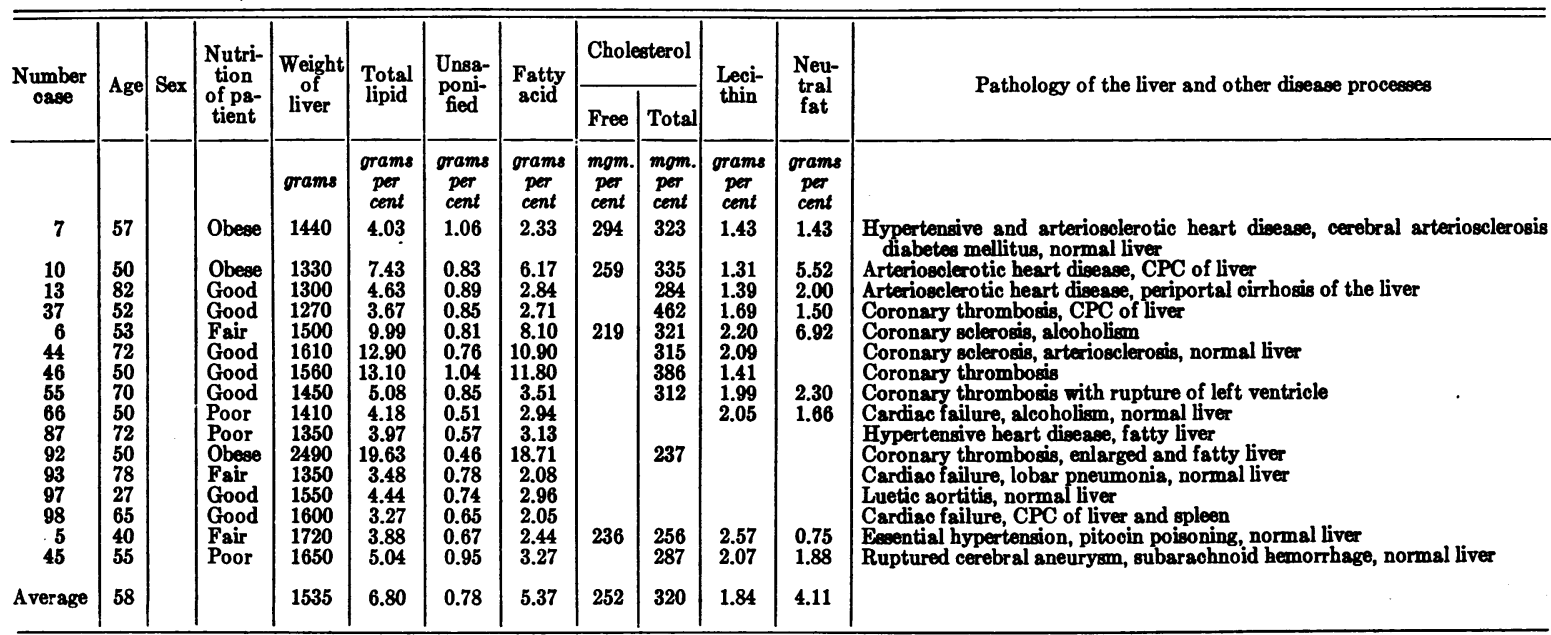


of 72 patients. Of these, 11 died of malignancy, 8 of tuberculosis, 10 of liver cirrhosis or atrophy, 4 in uremia, 6 of arteriosclerosis and hypertension, and 6 of pneumonia. The average total lipids in these groups varied from 4.72 to 7.68 grams per cent. The average total cholesterol varied from 312 to $277 \mathrm{mgm}$. per cent. In 1 of the cases of tuberculosis the total lipid was 20 grams per cent. In 1 of the cases of cirrhosis of the liver the total liver lipid was 12.5 grams per cent. The average total liver lipid for these two groups was not, however, elevated. The figures of Breusch and Scalabrino substantiate our findings. Apparently, the ability of the liver to handle fats is not easily impaired, and probably is only significantly affected when the liver itself is affected, as in cirrhosis.

\section{SUMMARY}

Analyses were done on 60 human livers. Of these, 16 were from patients dying of acute infections in whom no cirrhosis of the liver was found at autopsy. Five were from patients dying of acute infections in whom some cirrhosis or fatty infiltration was noted postmortem. Ten were from patients dying of chronic infections, 7 from patients dying with malignant diseases, 12 from patients dying with some disturbance of metabo- lism, and 16 were from patients dying with some form of heart disease.

The outstanding finding was in the 5 cases of acute infections in whom cirrhosis or fatty infiltration of the liver was present. The average total liver lipid in these cases was increased well above the normal range ( 15.48 grams per cent), and the total cholesterol was increased. There were no striking changes in the average lipid values in the other groups studied.

We are indebted to Dr. Douglas Symmers, Director of the Department of Pathology of Bellevue Hospital, and to the Department of Hospitals and the office of the Chief Medical Examiner for the samples of liver obtained for analysis.

\section{BIBLIOGRAPHY}

1. Ralli, E. P., Rubin, S. H., and Rinzler, S., The liver lipids in normal human livers and in cases of cirrhosis and fatty infiltration of the liver. J. Clin. Invest., 1941, 20, 93.

2. Boyd, E. M., and Connell, W. F., Lipopenia associated with cholesterol estersturtz in parenchymatous hepatic disease. Arch. Int. Med., 1938, 61, 755.

3. Rubin, S. H., Present, C. H., and Ralli, E. P., The liver lipids in normal dogs on different types of fat, with and without added lecithin. J. Biol. Chem., 1937, 121, 19.

4. Breusch, F., and Scalabrino, R., Die quantitativen verhältnisse der leberlipoide. Ztschr. f. d. ges. exper. Med., 1934, 94, 570. 